\title{
Corporate Democracy - A Transitional Step from Authoritative Power to Democratic
}

\author{
Valentin Y. Lyubashits ${ }^{1}$ \\ Alexey Y. Mamychev² \\ Anastasiya S. Kaminskaya² \\ Maria K. Filippova²
}

${ }^{1}$ Southern State University, ${ }^{2}$ Vladivostok State University of Economics and Service

Doi:10.5901/mjss.2015.v6n6s3p282

\section{Abstract}

The present paper considers "corporate democracy" as a political and legal and social and economic a phenomenon. The last one as the authors think acts is a transitional step from authoritative power to democratic. The paper analyzes the processes of democratic institutes formation in the transition period, in detail considers the role of institutes of the state in this process. It also examines changes which happened in property relations in the Russian Post-Soviet political and legal organization of society. The paper describes the merger process of bank and industrial capitals to the state in its specific "transitional" form, and also the feature of political and economic development of Russia in the transitive period. It proves that formation of society of owners is the indispensable basis of free democratic society, and establishment of the real property right will allow creating fullfledged civil society independent from the state. Thus, the paper points out that the "corporate" structures as a component of the system of functional representation are intermediate formation and they can be turned into both parties - both to "democracy of owners", and administrative "operated democracy".

Keywords: power institutes, state, democracy, legislation, institutional infrastructure.

\section{Introduction}

One of the important aspects of relations between the state and society revealing a character and dynamics of concrete relations, is an institutional aspect. The institutional infrastructure includes a various range of operating forces which everyone represent themselves in their own way. A number of political scientists point out, on one hand, the organizations of political representation - state agencies, political parties, etc., and on the other hand, various groups of interests included in the system of functional representation. The most essential structural element of functional representation is a corporation.

The subject of this research is the features of democratic processes in corporate structures of modern Russia in a comparative retrospect.

\section{Literature Review}

Before revealing special characteristics of corporate democracy in Russia as the system of functional representation, it is necessary to consider at least in general the main concepts of democracy and to reveal the conceptual belonging to them (concepts) of a corporate form of democracy.

Sh. N. Eisenstaedt's work "Paradox of democratic regimes: fragility and convertibility" (Eisenstaedt, 2002) where the author consider democratic regimes as a natural political institutionalization of Modernity with its increased need for variability and adaptability is one of the best known interpretations of democratic regimes specifics. Eisenstaedt analyzes constitutional operating concepts of democracy.

Both these concepts are rooted in the historical and ideological and institutional bases of the cultural and political program of modernity.

The constitutional treatment and a concept of democracy were formulated by $Y$. Shumpeter in his work "Capitalism, socialism and democracy" (Shumpeter, 1995). In contrast to "a classical doctrine" of democracy which proceeded from an idea of "general welfare" and the political system intended for its realization, Shumpeter defines 
democracy and its method as such institutional device for political decisions adoption in which individuals get power to make decisions by a competitive fight for votes.

If the constitutional treatment of democracy with all its modifications was mainly connected with the heritage of representative institutes and practices, then the operating versions are guided by the importance of participation at any level of public life including intermediary institutes or associations.

We are much interested in a position of community versions of operating democracy because they meet a research task of a corporate form of democracy. Representative bodies of power are considered by communitarists as important agents and instruments of deep inequality overcoming which disturbs the successful functioning of democracy. Enough careful perception of representative institutes is connected with fear that they not always promote a full participation of citizens in political life and can preserve an unfair distribution of power and wealth at any level of public life: at the level of a social community in general, a local community or a labor collective. Thus, the address towards economic democracy is not alien to a position of operating democracy (Lyubashits, Mordovtsev \& Mamychev, 2015).

Economic democracy is certainly connected with the democratic quality of society. T. Masarik claiming that genuine democracy includes not only political but also economic and social democracy is right. S. Ringen is the author of researches devoted to democracy problems, social policy and justice (Ringen, 2004).

Destruction of the institutional structure of capitalist society, and, therefore, its democratic method was promoted by a joint-stock form of the business organization, for all that, that this form was a product of the capitalist process. Proceeding from its commitment to fundamental values of private property and free contractual relations, the monopolization represented by corporation undermines viability of the capitalist system.

Such reasonings, probably, were entered in the neoclassical economic theory which till 1950 ignored a firm (corporation) as the most widespread form of the organization under capitalism and was concentrated on the explanation of the way how a theory of prices explains the market structure (Stigler, 1970).

F. von Hayek has given the conceptual estimates of the events which were close to Shumpeter. This period in the public structures development was called by Hayek "the corporate", "syndicalist" society. In the corporate society the organized branches will be something like enough independent states in the state. Subsidizing of many groups has started being determined not by market relations, and the results of economic processes, but by the course of political process, the strength of political representatives of various branches. F. Hayek expected such development of events only analyzing a gradual slipping of the western democracies through the growth of state regulation to totalitarianism (Hayek, 1990). Distributive conflicts infinitely tear apart the social and political fabric of society, make it extremely unstable and disorder.

The corporate society, where economics of the organized groups play the major role, is the closest analog of today's bureaucratic, "red-tape" economics. "The distributive conflicts" constitute considerable danger to society on the way to the market relations (Lyubashits, Mordovtsev \& Mamychev).

At the turn of the XIX-XX centuries E. Bernstein who are one of the most famous critics of Marxism and heralds of economic democracy has called one of the cornerstones of the Marxist theory about general destroying crisis of the capitalist system of production into question. The crash of the system is improbable owing to adaptability of the industry, the strengthening of its differentiation. Means of capitalism adaptation are: 1) development of the credit system, improvement of communications, businessmen's organizations; 2) stability of average estates; 3) improvement of the economic and political situation of the proletariat.

In the increased number and value of joint-stock companies, in practice of a share issue Bernstein has caught a factor of decentralization and democratization of the capital that causes the increased number of the owners, i.e. the expansion of a middle class, the growth of welfare of workers. E. Bernstein saw the future of the labor movement and socialism in the need for the strengthening of the society control over conditions of production including by means of the legislation, the expansion of economic democracy.

It was not Bernstein who started the theoretical development of these questions, he used (and did not hide it) conclusions formulated on the basis of an analysis of a large number of statistical data of G. von Schulz-Gewerniz and the scientists who left Brentano's school, the economists Gerkner, Zintskheymer, and also Yu. Wolf.

So, Schulz-Geverniz in his book "Large Production" made a conclusion about equalizing of property contrasts because the work receives the increasing share of the total national income, and this process does not make the rich richer and the poor poorer, but does the opposite.

P. Sorokin in his classical work "Social and cultural mobility" (1927) mainly used the same number of statistical data known also to Bernstein and conclusions of the scientific sociological research coincided in essence with conclusions of a reformist Bernstein (Sorokin, 1992).

An idea of the fight for economic democracy as an effective method of gradual introduction of socialism is taken to 
the next stage of development in the program documents of a reformist part of the labor movement in the 20-30th of the XX century. So, a new SPD program accepted in Heidelberg (1925) does not set the problem political power taking by a working class: the way to socialism had to go through "economic democracy", the current parliamentary democracy has to be added with democracy in economics.

This subject line became a keynote in social democracy activity. The basis of the modern program installations was laid by the document accepted by German social democrats in Bad Godesberg in 1959 and which had a great theoretical value for international social democracy of that time.

An idea of the fight for comprehensive political, economic and social democracy became a postulate. The problem of the control of economic power demanded a special attention.

A part of the draft of the Godesberg program devoted to economic principles, economic SPD policy, relationships of property and power was prepared by H.Dayst, an expert of the party (1902-1954). Dayst has managed to defend the concept which was included into the the Godesbergs program. A concept essence is in the following. The autonomous development of economy which is based on market principles at the limited intervention of the state and existence of the public enterprises provides an equitable distribution of the income and property that actually will mean the movement towards socialism (Lyubashits, Mordovcev, Mamychev \& Vronskaya, 2015).

Dayst, having investigated the process of concentration in the sphere of production which led to the change of the whole structure of economy has noted that concentration of power became the most characteristic structural sign of economy. Economic power influences political institutes - the government, the parliament, governing bodies (Jahrbuch, 1977).

\section{Methods and Materials}

There are certain bases to use the methodological approaches of the outstanding economists and sociologists Shumpeter and Hayek for an analysis of democracy problems not in the conditions of the transition from capitalism to socialism, and, on the contrary, in the transition from socialism to capitalism.

We can observe a coincidence point (a return point?) of two tendencies of an opposite character. One, conducting to "the socialist future" - the western democracy as it seemed in the 40th years of the last century and the other - to "the capitalist past" as it is today presented at the turn of two eras.

Then we can offer the thesis according to which "the corporate" structures are the intermediate formation and they can be turned into both sides - to the market, and to the administrative condition. Such system is some kind of criterion of reversibility/irreversibility of public transformations. Probably, the corporate base is that an intermediate step which society, breaking off with totalitarianism, is compelled to pass in reverse order.

We have already noted that corporate democracy is one of the kinds of economic democracy.

The democratic perspective from the point of view of corporate processes has big enough history. Community versions of operating democracy have especially fully shown their worth in the social democratic theory and practices.

\section{Results and Discussions}

Concentration of economical authority leads to concentration of political authority. Hence it follows the goal to establish an effective democratic control over economical authority by means of competition, legislative and financial support to medium and small enterprises of different forms of ownership.

The "democratic" or "public" control is becoming one of the key notions in the social democratic theory and practice. The theoretical position of democratic socialism corresponds with the practical direction of social democrats.

We can mark three aspects, greatly considered in economic policy: 1) "the property accumulation of workers"; 2) "the involvement in management"; 3) "assented shares".

Thus, the economic democracy, being an instrument of control over the authority, needs the social involvement in economic decisions.

In practice, the social democrats were able to carry out the ideas of social control, in terms of using such a tool as a state, in order to develop social and distributive policies.

From the mid 1980s new involvement forms of wage workers in industrial business activity have become widespread. A new system of so called "involvement economics" ("involvement system", "involvement democracy") was formed.

The problem of how to motivate a worker, to create conditions for revealing their creative potential, for involvement a worker in the decision making process, started in a new way. 
The main involvement system forms include: a) the involvement in profits, or in "enterprise's success"; b) the involvement in property; c) the involvement in management.

\subsection{The involvement in profits}

France has achieved the greatest advances in the involvement system of wage workers, because this system has been practiced there since 1959. In 1990 the personal pay system for higher categories of workers on large enterprises (over 500 people) was used by $87 \%$ versus $36 \%$ in 1983 , the collective interest in "enterprise's success" was used by $46 \%$ versus $7 \%, 44 \%$ of enterprise's workers had the savings plans on accounts of the enterprise versus $16 \%$, etc.

System of individualized salaries employed $87 \%$ vs. $36 \%$ in 1983, the collective interest in the "success of the enterprise" is used $46 \%$ vs. $7 \%$, savings plans in the accounts of the company there were $44 \%$ versus $16 \%$, etc.

The involvement system in France became to acquire the trait of the "collective interest". In the USA the involvement system spans $22 \%$ of all the employed. The distribution of shares among the company stuff is widespread.

There were 430 thousand plans of involvement in profits on the American enterprises in all. More often such participation is carried out in the form of "deferred payments" (pension funds).

In Great Britain a share of holders among the population of the country has grown within the 80 th from $7 \%$ to $20 \%$ having reached a figure in 10 million persons.

In Japan this form is an important factor of the high level of labor motivation of workers and the high competitiveness of Japanese economics.

\subsection{Participation in property}

The economic democracy solves at least the problem of decentralization and democratization of property. Decentralization of property is understood as a distribution of the share capital of corporations among citizens. What does the connection of labor with the means of production in a managing form main for today - a corporation experience?

The basis of a corporation is the societies with the share capital. The joint-stock partnership becomes dominating. In the USA, Western Europe from 80th the holders of the shares of the largest corporations are tens of millions of people. In the USA 47 million shareholders among whom every third adult is American, in Great Britain and France - 9-9,5 million people - every fifth adult is Frenchman and Englishman, 8,5 million people - every fifth adult is Frenchman and Englishman, 8,5 million - in Japan, 1,2 million - in Germany.

\subsection{Participation in management}

The creation of collective property is inseparable from the problem of power and control. The begun process of property democratization causes also democratization of management.

The control over the use of means of production is an obligatory element of the self-government of direct producers. The self-government in the USA, as Ya. Keremetsky thinks, for example, is perceived as "non-hierarchical form of the organization of production and the democratic process of administrative decisions making" (Keremetsky, 1990; Shkurkin et al., 2015).

Democratization of management is carried out at the different levels: sites, shops, enterprises and firms. The average and the lowest administrative positions solve the technical issues connected with the increasing efficiency production. The factory committees of management assume management of production, their main function is a discussion and decision-making concerning the production sale, the purchase of the equipment, the technological process improvement, the employment of workers and managing directors and other important problems of production.

At all features the systems of participation in management in the USA, Germany, France and other countries are united by some general moments. The right of decision-making is realized in three spheres which concern the organization of work, its regulation (duration of the working hours, holiday, etc.), the forms and the level of salary. Workers are attracted as consultants for questions of a scientific and technical character, a policy of employment.

However, the hierarchy of management remains in such decisive areas as investment, technical, personnel policy, distribution of profits. 


\subsection{The presented picture on democratization or diffusion of property which occurred in developed countries in the second half of the XX century shows the main vector of development of economic democracy in Russia, especially in its corporate sector}

The most important instrument of deep inequality overcoming in society is realization of the right of private property. Let's have in view that in understanding of "private property" in modern political economics there were certain motions. Let's remember Shumpeter's thought of "emasculation of the idea of property" in a corporation (instead of walls and the foundation is a pack of pieces of paper).

In theoretical models describing the functioning of property, property on production factors, first of all, on material and financial assets, and also on the human capital were often starting points of an analysis.

Thus, it is supposed that the results of all transactions of an owner in the market are fixed by contractual arrangements. Today the following circumstance is essentially important: no signed contract can be considered as enough "full". When the matter concerns the contracts providing the employment of labor or the rent of any property (production equipment) it is impossible to foresee all situations which can be and in advance define the rights and obligations of the parties in each of these cases.

In these cases the property rights are first of all found in connection with incompleteness of the contracts. Therefore, the property rights are defined in institutional economics as residual in relation to requirements of a contract the rights of the order and control.

Giving this definition, neoinstitutsionalists emphasize that this approach assumes economics in which there are not only the debugged structure of agreements which are making out the results of market transactions but also "culture of a contract" cultivated during many decades. A definition of property through the residual rights assumes that participants of the economic process are sure of contractual obligation reliability.

Formal, but not real registration of the private property institution in the USSR has happened on spring in 1991. Before cosmetic reforms like granting economic independence to public industries were carried out four years, private property like "the right of full economic maintaining", permissions of the cooperative and rent enterprises were invented. At the turn of 1990-1991 a position about privatization inevitability in the USSR and Russia is approved, without what in the presence of the dominating public sector - it is impossible to speak about the right of private property, about actions and securities markets or other attributes of market economics.

The law of the USSR "On property in the USSR" of 6 March, 1990 and the amendments to the Constitution of the USSR of 14 March, 1990 (Art. 10-13) allowed the existence in property of citizens both non-state legal entities of means of production, securities and other material and non-material objects and the rights which bring the income.

Of course, the principle of full recognition and protection of all forms of ownership is closely connected with political pluralism and democratic values. The principle of absolute protection of the property rights recognized as a priority of the state causes stability of the political system and increases the trust of the population to its institutes. On the contrary, real democratic institutes and procedures of decision-making allow most fully and with the minimum costs for society to realize a balance of interests of various subjects of property. Following these principles means also recognition of the international standards developed by the world community in the second half of the XX century. In the context of processes of globalization of the world economics effective protection of the property rights at the national level means the formation of favorable conditions for economics integration of Russia into the international economic space.

The Russian history notes the following main stages of property redistribution: the spontaneous privatization process (1987-1991); mass privatization (1992-1994); post-privatization redistribution of property (concentration of the sprayed stocks of privatized enterprises since 1993 as the most general process; mortgage auctions of 1995; wars of "oligarchs" of 1997; the transition from criminal to legal procedural technologies of the corporate control and the share capital redistribution in 1996-2004).

\subsection{Post-privatization property redistribution took place against the general process of consolidation of the control in Russian corporations}

The conflict between old managers who are fiercely defending their positions and potential "aggressors" of the control was the basic conflict during all these years.

The transformation of corporate institutional characteristics includes two substages.

First, the phase of 1995-1997 is connected with completion of property repartition in a number of the key companies of Russia. As a result of transfer to a group the most influential banks of a number of the profitable exportoriented enterprises of oil and metallurgical branches in the country there were created some real corporate structures 
large which were under control of banks. They were given the name FIG (financial and industrial groups) or conglomerates (As the Federal commission on Securities (FCS) says, in 1996 the fight for the control came to the end in $25 \%$ of Russian corporations, at the beginning of 1998 - in $50 \%$.).

Secondly, owing to emergence of legal restrictions connected with coming into effect the law "On Joint-stock Companies" and other standard and legal documents from the second half of the 90th to the beginning of the 2000th procedural receptions including with the violation of the corporate legislation were used in the fight for the control.

In the conditions of transitivity of the Russian society and its economics the uncertainty zone in the sphere of the property rights has extended because the system of protection of state ownership is washed away, and the new accurate system of the rights of private property is still absent. Blurring of the property rights leads not only to paralysis of the investment activity of corporations but also to difficulties of the process of corporate (economic) democracy institutionalization. It is clear that historically (traditionally) the developing structure of property distribution in a corporation defines specific national models of the corporate management and the corresponding democratic mechanism.

It is necessary to be noticed that a number of questions, which are basic for development of the Russian model of the corporate management, was investigated in 1998-2004 (Radygin \& Entov, 1989; Radygin \& Entov, 2001; Kobersy et al., 2015). The researches notes that the legal environment and the structure of economics of Russia are so specific that it is important to try to construct a special - "Russian" - model of the corporate management. Its special characteristics are:

First, opacity of the structure of property caused, in particular, by an illegitimate nature of privatization and the subsequent repartitions of property;

Secondly, imperfection of the Russian legal institutes changes our ideas of interrelation between the corporate management and the structure of property. In the western researches the structure of property is endogenous in relation to the legislative level of protection of investors' rights of. In economics with the developed financial markets and the system of protection of the property rights and contracts performances the structure of the capital and, in particular, the structure of property are endogenous and are defined by the structure of business, the distribution of the income, the size of an enterprise, a uncertainty nature etc.

At the same time existence in Russia of high transactional costs at the capital market leads to the fact that the structure of property changes very slowly. It is impossible to claim that the structure of property is exogenous because after privatization there was enough time a considerable redistribution of property has happened (Mordovtsev A.Y., Mordovtseva T.V., Mamichev A.Y., 2015). Nevertheless, the structure of property changes more slowly than the level of corporate management therefore it is considered as an exogenous variable. The low level of laws performance makes the corporate management from the formal into informal institute. In developed countries the level of protection of the investors' rights is defined by the legislation and therefore is considered as the set value. In Russia the corporate legislation is not carried out, therefore protection of the rights of external investors is not obligatory, but is voluntary, a company chooses itself the level of its execution (Guriev, Lazareva, Rachinsky \& Tsukhlo, 2004).

Identification of political and legal conditions forming the optimum institutional environment including democratic procedures represents is very difficult task. So, for example, B. Weingast points out "a fundamental political dilemma of the economic system": the government which is enough strong to protect the property rights, is at the same time enough strong to confiscate also property of citizens (Weingast, 1993). The law-enforcement actions proceeding from political reasons which are shown in the form of a selective (made to order) inforsment concerning "Yukos" testifies to it.

\section{Conclusions}

1. The formation of democratic institutes in a transition period is shown in a special role of the state as "a creative destroyer"; it demands the longer period of time for this process comparable to the whole transition period. Creation and performance of the effective legislation, "filtration" of the limited interests of any type (political, populist, criminal, etc.) demand the daily regulatory activity of the state. Such activity of the Russian state can lead to realization of the absolute principle of "inviolability" of property that is adequate to non-interference of the state to the developed structure of democratic institutes.

2. Despite really serious changes which have happened in the property relations, in economics of the modernized Russia a serious gap between the nominal and real property rights continues to be, and in certain cases the rights of the real control remain in the hands of old/new political and economic nomenclature. Thereby, forming private property in many cases continues remains to have a "non-market", non-democratic character, and redistribution of such property is made according to political and other reasons which are quite often poorly connected with any care of the effective use of acquired property. The economic democracy in 
many respects continues to have a nominal character.

3. Moreover, the merger process of the bank and industrial capitals to the state in its specific "transitional" form is carried out. It generates not only positive consequences, but also provokes the fight of the limited (private and/or state) interests, and, so conducts to some subordinate preference, "special relations" of certain economic subjects with the state, corruption, criminals etc. Thereby, "procedural uncertainty", by which the transition from the «ordered» attitudes of the centralized management towards the political democracy and to the statement of economic freedoms is characterized, becomes stronger. Possibility of the address or towards practice of "the operated democracy", or "democracy of owners" remains.

4. The feature of the political and economic development of Russia in the transitive period generate a specific situation when privatization of a number of state enterprises and new private firms distribution are not followed by the development of an adequate mechanism of the inforsment of the property rights, i.e. a mechanism which would provide reliable enough realization of relations assumed by the rights of private property. In this case the sense of private property definition through the residual rights is lost. The low level of protection of the property rights was and to a great extent remains in the 2000th favorable to many economic agents because it creates favorable conditions for the further redistribution (repartition) of property. A potential of "corporate and bureaucratic polyarchy", "operated democracy" continues thereby to be.

5. the other feature of the corporate democratic practice is absence, both in practice and in social historical memory of the Russian population of information on presocialist market institutes unlike a number of the countries of the Central and Eastern Europe. So, the experts in the field of development of financial markets give comparative data on the investment Russian funds across Russia and across a number of the countries of Eastern Europe: in absolute expression the total net assets of the investment funds of Poland, Hungary and the Czech Republic exceed the similar indicator across Russia by 5-7 times, it is noted the gap divisible by 80 per capita (An Analysis, 2003).

6. The formation of society of the owners is the indispensable basis of free democratic society. The establishment of the real property right will allow creating the full-fledged civil society independent from the state. Exactly privatization is an absolute imperative for the way out from socialist feudalism. First of all, the gradual stabilization (ordering of the structure) of the property rights became the general positive result of the difficult and inconsistent process of formation of the structure of property in Russia: from the amorphous and disperse structure to emergence obvious (formal, based on the property right) or hidden (informal, based on real power in corporation) poles of the corporate control. This process was closely connected with positive changes in the sphere of the standards of the corporate law, the legislation in general, the fixing system of functional representation.

7. "Corporate" structures as a component of the system of the functional representation are the intermediate formation and they can be turned into both sides - to "democracy of the owners" and to administrative "operated democracy". However, creation of prerequisites of democratic institutes stability is interfered by the absence of a tradition standing behind them, forming by many decades if not centuries "culture of a contract", providing historical legitimation of the corporate democracy.

\section{References}

The analysis and the forecast of the development of the financial markets in Russia (2003). M.: TASIS.

Guriev, S., Lazareva, O., Rachinsky, A. \& Tsukhlo, S. (2004) The corporate management in the Russian industry. Moscow.

Keremetsky, Ya. (1990) Democracy on production and collective property in the USA//Economic questions. №9.

Lyubashits, V.Ya., Mordovtsev, A.Yu. \& Mamychev, A.Yu. (2013) Government: paradigm, methodology, typology. M. pp. 412.

Radygin, A.D. \& Entov, R.M. (1999) Institutional problems of the development of a corporate sector: property, control, securities market. M.: IEPP.

Radygin, A.D. \& Entov, R.M. (2001) The corporate management and protection of the property rights: an empirical analysis and the actual directions of reforms. M.: IEPP.

Shkurkin, D., Novikov, V., Kobersy, I., Kobersy, I., \& Borisova, A. (2015). Investigation of the scope of intellectual services in the aspect of virtualization and information economy of modern Russia. Mediterranean Journal of Social Sciences, 6(5S3), 217-224. doi:10.5901/mjss.2015.v6n5s3p217

Ringen, S. (2004) The distributive theory of economic democracy//Logos. №2.

Sorokin, P. (1992) People. Civilization. Society. M.

Hayek, F.A. (1990) Road to slavery//Philosophic questions. №10.

Shumpeter, Y. (1995) Capitalism, socialism and democracy. M. 
Eisenstaedt, Sh.N. (2002) Paradox of the democratic modes: fragility and convertibility//Political researches. № 2-3.

Kobersy, I. S., Barmuta, K. A., Muradova, S. S., Dubrova, L. I., \& Shkurkin, D. (2015). The system of the methodological principles of management of enterprise development. Mediterranean Journal of Social Sciences, 6(3S4), 25-30. doi:10.5901/mjss.2015. v6n3s4p25

Lyubashits, V.Y., Mordovtsev, A.Y., Mamychev, A.Y. (2015) State and Algorithms of Globalization//Mediterranean Journal of Social Sciences. Vol 6, No 3 S6. pp. 269-277.

Lyubashits, V.Y., Mordovcev, A.Y., Mamychev, A.Y. \& Vronskaya, M.V. (2015) State: Typological Analysis of Evolutionary Forms//Mediterranean Journal of Social Sciences. Vol 6, No 3 S4. pp. 75-83.

Mordovcev, A.Y., Mordovceva, T.V. \& Mamichev, A.Y. (2015) The Convergence of Law: The Diversity of Discourses//Mediterranean Journal of Social Sciences. MCSER Publishing, Rome-Italy. Vol 6. No 3. River. pp. 262-270.

Jahrbuch der Sozildemokratischen Partei Deitschlands. 1975 - 1977. (1977) Bonn - BAD - Godesberg.

Stigler, G. (1970) The Organization of Industry. Homewood., II: Irwin Press. pp. 768.

Weingast, B. (1993) Constitutions as Governance Structures: Political Foundations of Secure Markets//Journal of Institutional and Theoretical Economics. Vol. 149. pp. 286-311. 